\title{
Anglican Theology in the Midst of a Migration Crisis $^{1}$
}

\author{
Jesse Zink $^{2}$ \\ jessezink@montrealdio.ca
}

\begin{abstract}
This article explores what Anglicanism may have to say to a world struggling with a 'migration crisis'. It begins with the story of the nineteenth-century African martyr, Bernard Mizeki, who was both a migrant and, as a missionary, a place-maker. Using three pairs of words - place and displacement, guest and host, and journey and destination the article connects Anglicanism's historic emphasis on parishes and the Incarnation to contemporary thinking on migration. It argues that eschatological thinking is necessary so Christians can consider what sort of destination they offer in their communal life. It concludes by urging more study of the relationship between migration, Anglican identity, and Christian being in the world.
\end{abstract}

KEYWORDS: Anglicanism, displacement, eschatology, guests, hosts, Incarnation, journey, migration, mission, Bernard Mizeki, refugees, Zimbabwe

It is a commonplace to say that we live in an era shaped by migration and the movement of people. Indeed, the phrase 'migration crisis' is often used to describe the current global situation. Stories from places as diverse as Myanmar, the Mediterranean, Syria, and the US-Mexico border remind us that migration remains one of the most important factors in the world today. To be asked to speak about Anglicanism and

1. This article was the keynote address to the Society for the Study of Anglicanism meeting at the American Academy of Religion Annual Meeting in Boston, Massachusetts on 18 November 2017.

2. The Revd Dr Jesse Zink is principal of the Montreal Diocesan Theological College, Canada. 
migration, therefore seems absolutely proper but also almost entirely overwhelming.

It is overwhelming because the scale of our present migration crisis is overwhelming. The United Nations High Commissioner for Refugees reports that there are now more people displaced in the world than at any point since the end of World War II, some 65 million. That number conceals greater complexity: of that 65 million, about 22 million are formally classified as 'refugees' - people who have been displaced across international borders - while the rest are internally displaced, that is, people who have been forced to leave their homes but remain in their countries of origin. ${ }^{3}$ The overwhelming nature of this topic is also manifest in the number of issues to which migration is connected. When we speak about migration, we may also find ourselves speaking about human trafficking, inequalities in the global economy, and civil wars, to name just three issues that may properly be considered alongside migration.

While these high-profile examples of migration are in the news though it is shocking how quickly the world has allowed itself to become inured to repeated stories of migrants drowning in the Mediterranean - a further part of the complexity of the issue is that the movement of peoples takes many forms. I am sure, at an academic conference such as this one, we will find plenty of migrants, that is, people who have moved for education, opportunity, or work. In our world there is an elite class of consultants, bankers, and lawyers who seem to be constantly on the move and often live and work outside their home countries. In this context, I should note that I, too, am a migrant. I have lived in four countries in my life, having moved for reasons of work, education, and adventure. These are all examples of a whole class of the movement of people that is generally not considered part of our 'migration crisis' but should also be seen as part of the topic of migration.

Given the complexity of this issue, I want to proceed as follows. First, I will tell one story that I believes highlights some of the central issues related to migration. Then, I will introduce three pairs of words that I think helpfully frame some of the theological issues raised by migration and will I hope provide a spark for further conversation. Those word pairs are: place and displacement, guest and host, and journey and destination.

3. United Nations High Commissioner on Refugees, Global Trends Report 2016, available at: http://www.unhcr.org/globaltrends2016/ (accessed 5 December 2017). 


\section{The Migrant Missionary}

Mamiyeri Mizeki Gwambe was born in about 1860 near Inhambane in what is now southern Mozambique. ${ }^{4}$ At about age sixteen, he set sail for Cape Town, South Africa as part of a labor importation scheme. He worked, variously, on the docks, as a gardener, a domestic servant, and a stablehand. As the colonial presence deepened in southern Africa, a younger generation was coming to realize that they needed new skills to adapt and survive and that there were new opportunities created by the growth of colonial centers. Mamiyeri Mizeki Gwambe was not, perhaps, unlike the young people who are now leaving their homes in West Africa, crossing the Sahara to Libya, and seeking a new home across the Mediterranean in Europe. They may not have a particular plan in mind when they leave home but they believe that the combination of opportunities there is greater than what is available to them at home. With other people from Mozambique in Cape Town, Mamiyeri began attending a night school overseen by the Society of St John the Evangelist. A few years later, he was baptized. He took the name Bernard and became known as Bernard Mizeki.

This act of movement happened against the background of increasing colonial presence in southern Africa. In 1888, Cecil Rhodes conquered what is now Zimbabwe and opened it to European development. Church structures responded accordingly. Anglicans created the missionary diocese of Mashonaland and in 1891 Mizeki became one of several 'native catechists' who accompanied the missionary bishop George Wyndham Hamilton Knight-Bruce to the region. In time, Mizeki was sent to settle in the territory of a Chief Mangwende - in what is now southern Zimbabwe - among the Shona people. In many ways, Mizeki was a conventional missionary of the time. He learned the local language, led prayers and worship, taught hymns and gave singing lessons, and translated portions of the Bible into Shona. He supported the introduction of Western medicines and vaccinations, particularly at a time when smallpox threatened the region. He was largely welcomed by Mangwende's people. His special patron was Mangwende's senior wife and Mizeki himself in time married

4. My account of Bernard Mizeki is drawn from Jean Farrant, Mashonaland Martyr: Bernard Mizeki and the Pioneer Church (London: Oxford University Press, 1966); Dana Robert, Christian Mission: How Christianity Became a World Religion (Malden, MA: Wiley-Blackwell, 2009), pp. 159-72; Patrick Harries, 'Culture and Classification: A History of the Mozbieker Community at the Cape', Social Dynamics 26.2 (2002): 29-54; and Mark Noll and Carolyn Nystrom, Clouds of Witnesses: Christian Voices from Africa and Asia (Downers Grove, IL: IVP Books, 2011), pp. 21-32. 
Mangwende's granddaughter. Some of the early catechumens encountered resistance and hostility from their family members and so Mizeki had to find places for them to live. He began to grow a small community around him.

The first part of Mizeki's story is one of migration: first from his home in Mozambique to Cape Town and then from Cape Town to Mashonaland. Yet from his arrival in Mashonaland, Mizeki's story shifts and becomes one of place-making. He has a small community around him and he joins the kinship networks of the chief. We might say that he begins to 'settle down'. A key moment in this settling down came around 1894. In that year, Mizeki received permission to move his settlement to a grove near a stream that flowed out of a mountain. This grove was sacred to some Shona. On his arrival, Mizeki cut down some trees, built a garden, and planted wheat, an imported crop. Mizeki was urged to make an offering to the ancestral spirits of the place but he refused. Instead, he carved crosses into the trees around the perimeter of the site. It is easy to see the challenge Mizeki represented. He was a challenge to existing structures of religious authority. He dismissed traditional ritual experts and healers and said that prayer worked better than animal sacrifice to spirits. This was an economic challenge as well: if people prayed instead of sacrificing an animal, ritual experts lost out. If diviners lost their sacred grove, there would be fewer sacrifices. And Mizeki posed a challenge in his way of life: he represented literacy, medicine, and agriculture - in a word, modernity.

You may know how this story ends. In 1896, the Ndebele and then Shona rebelled against the British, a rebellion led by traditionalist religious authorities. Mizeki was told to retreat from his station but he refused: 'Mangwende's people are suffering. The Bishop has put me here and told me to remain. Until the bishop returns, here I must stay. I cannot leave my people now in a time of such darkness. ${ }^{5}$ On June 18 , 1896, three male relatives of Mangwende came to the mission, stabbed Mizeki with a spear, and left him for dead. As Mizeki's wife and another woman went to get supplies to help him, Mizeki crawled to the stream. The women heard a noise like many birds' wings and saw a blinding white light. When they came back, the body was gone. As Jean Farrant writes, 'It is left to the individual Christian mind to accept or reject the supernatural light, but it seems certain that something happened that night which to the Africans was beyond explanation, which frightened them very much, and made a deep impression. ${ }^{6}$

5. Farrant, Mashonaland Martyr, pp. 208-209.

6. Farrant, Mashonaland Martyr, pp. 222-23. 
Since 1896, the memory of Bernard Mizeki has been contested and commemorated in various measure. When I lived in South Africa, the Bernard Mizeki Society was a major organization for Anglican laymen in my local parish. There is now a major celebration at the site of his martyrdom every June that unites people from Mozambique, South Africa, and Zimbabwe. I will leave this for another time. I have told Mizeki's story because I think it provides an opportunity to explore several questions related to migration and Anglicanism at greater length, an exploration I will frame using three word pairs.

\section{Place and Displacement}

Migration, of course, is about movement. The implication of migration, therefore, is that there is a place that is left behind. That is why forced migration is called displacement, as when people are forced to leave their homes because of the violence of civil war. Syrian refugees in Lebanon or Jordan are displaced precisely because they have left their place behind.

Bernard Mizeki's story is one of migration. He left behind a place in Mozambique for Cape Town and then left that place behind for Mashonaland. Whether these decisions were voluntary, his story of migration is related to the departure from particular places that had meaning for him. But his story also involves place-making. In Mashonaland, this was most evident in the new community of catechumens gathered around him, his marriage, and above all in the sacred grove that he took over and where he is still commemorated. That act of place-making was experienced as displacement by others, a point to which I will return. In talking about faith and migration, therefore, we must first acknowledge that faith and place are deeply intertwined. It is only possible to speculate about the influence of the Society of St John the Evangelist on Mizeki but recall the rule of St Benedict and its emphasis on place. One of the vows Benedictine monks take is of stability, that is, of connection to a particular community in a particular place.

It is often widely noted how themes of migration are threaded throughout the Bible: the great commands to remember aliens and strangers, for instance, or the utter catastrophe of exile. But it is also true that the Bible is shot through with the theme of place. Creation is the story of the creation of a place, the Garden of Eden, and with it an implicit vow of stability: stay in this place, dwell here, and have abundant life here. Among much else, the Fall is a moment of displacement. Eden is no longer the place from which Adam and Eve can take their identity. Later, Abram is told to get up and go to the land that 
God is showing him (Gen. 12.1-3). As the author of Hebrew notes, this willingness to move is a sign of faith: 'By faith Abraham obeyed when he was called to set out for a place that he was to receive as an inheritance; and he set out, not knowing where he was going.' But his movement was ultimately linked to a place: 'For he looked forward to the city that has foundations, whose architect and builder is God' (Heb. 11.8, 10). Similarly the Exodus is a story of divine displacement that leads to the creation of a new place in the Holy Land, a creation which in turn displaces many other people, often violently. In these stories, displacement leads to place-creation.

The significance of place in the Hebrew Scriptures is closely related to the well-known sympathies in these writings for people on the move. For instance, we read in Leviticus, 'The alien who resides with you shall be to you as the citizen among you; you shall love the alien as yourself, for you were aliens in the land of Egypt' (Lev. 19.34). This is a reminder to the Israelites that as they create a place for themselves, they must also remember to create a place for those without one. As they remember that they too were once without a place, they are to remember those without one now. In a famous passage in Deuteronomy, the Israelites are told to summarize their identity as follows: 'A wandering Aramean was my ancestor; he went down into Egypt and lived there as an alien' (26.5). But they are told to remember this: 'when you have come into the land that the Lord your God is giving you as an inheritance to possess, and you possess it, and settle in it' (26.1). That is, when they make themselves a place which will form them as a people, they should remember that their identity is rooted in their alien ancestry.

There are good reasons for this emphasis on place. In societies like those described in the Hebrew Bible, economic production was closely tied to the land. So was identity: where you came from mattered a great deal. Particular places expressed religious identity, whether in the altars that patriarchs built across the Holy Land or in single sites like the temple in Jerusalem. Place is particular and concrete. That is where it derives its importance. It is here, not there. It is noteworthy, therefore, that the Hebrew Scriptures should so consistently tie place and displacement together.

I want to borrow an insight from an article written by Oliver O'Donovan more than 30 years ago and titled 'The Loss of a Sense of Place'. He writes: 'the Old Testament is full of the sense of place, but the New Testament is indifferent to it'. ${ }^{7}$ There are good reasons for thinking

7. Oliver O'Donovan, 'The Loss of a Sense of Place', in Oliver O'Donovan and Joan Lockwood O'Donovan, Bonds of Imperfection: Christian Politics, Past and Present (Grand Rapids, MI: Eerdmans, 2004), pp. 296-320 (307). 
this. The dominant theme of the New Testament literature is one of displacement, of not belonging. Jesus, as we have been reminded recently, was a refugee in Africa. After his expulsion from Nazareth, he never had a permanent base in his ministry. He sent his followers out on the road to follow him in similar fashion. In his teaching, he at times deprioritized place, as for instance when he told the Samaritan woman at the well: "The hour is coming when you will worship the Father neither on this mountain nor in Jerusalem... the hour is coming, and is now here, when the true worshipers will worship the Father in spirit and in truth' (Jn 4.21, 23). Jesus also equated himself with the Temple. His migratory nature and focusing of religious authority on himself deprioritizes the particularity of the Temple's location. As O'Donovan and others have argued, the salvific vision in the Old Testament was tied to a particular place, the Promised Land, but in the New Testament the vision of salvation is spaceless and intellectual.

There is no doubt good reason for all of this. The Roman Empire was a transient place. New colonies were often created of people from around the Empire. Still, it is noteworthy that the early Christians described themselves as a people without particular place. The First Letter of Peter, for instance, is addressed to 'the exiles of the Dispersion' (1.1) and calls them 'aliens and exiles' (2.11). A key passage in the letter is in 1.17: 'live in reverent fear during the time of your exile'. The key word in Greek is paroikia, meaning elsewhere in the Bible stay, sojourn, or exile. When Paul preaches in Antioch in Acts, he refers to the paroikia of the Israelites in Egypt (Acts 13.17). Christians are people like those Israelites: the descendants of that wandering Aramean who went to Egypt as an alien.

The legacy of Establishment and the claim to be a national church have historically tended to make the Church of England, and by extension Anglicanism, a faith that emphasizes place. It was not until I lived in England that I realized how fundamental the idea of a parish is. One simply cannot close churches as quickly as one may think necessary because their very stature on the landscape gives meaning to people in that place, even if they never darken the door of the church. ${ }^{8}$ Yet we should also note that the very word 'parish' drives us back to displacement. Parish is derived from the same Greek word used in First Peter and in Acts: paroikia, meaning stay or sojourn. The parish I was associated with in England had on its wall a list of rectors that went

8. At the time this was delivered, I was aware of but had not yet managed to get a copy of Andrew Rumsey's Parish: An Anglican Theology of Place (London: SCM Press, 2017). 
back to the Domesday Book and the time of William the Conqueror. This particular parish, it seems, was in the midst of a rather extended period of exile, so extended in fact that it had become a permanent place. That is precisely what makes parish churches appealing to so many people: rather than being there only temporary, they are attractive because they have been there so long and so indelibly shaped particular places. Yet in the very word 'parish', at the heart of how many Anglicans understand church, we are reminded that Christianity brings with it both a commitment to place but also an acknowledgment of the reality of displacement. Bernard Mizeki embodied this: he left places behind and he also created new ones. It was both displacement and place-making that shaped his religious identity.

\section{Guest and Host}

Bernard Mizeki was someone who spent time as a guest. He was a guest of SSJE in Cape Town and a guest of Mangwende in Mashonaland. It is fair to say, I think, that we have an implicit expectation that migrants will have a relationship of guest to the hosts in the land where they arrive. Even when the language is not used explicitly, the relationship is recognizable. People in refugee camps are effectively seen as guests of international humanitarian agencies, even as this often overlooks the tremendous agency and vibrancy of refugee life. Part of the rhetoric that opposes migration is that migrants will take resources that are rightly spent first on citizens of the receiving country. In other words, migrants will become guests in an environment in which it is argued that guests cannot be afforded.

But Mizeki was not just a guest. He was also a host. As he created a new place in Mashonaland, he also welcomed converts and hosted them. His hospitality was part of his creation of a new place. This is less often remarked about migrants but no less true: as migrants come into our midst and create places, they also become hosts. After beginning ministry in Montreal I attended services at some diasporic churches, usually African-founded Pentecostal denominations that have come to Canada along with African immigrants. Even though I am ostensibly the native-born and the people in church are recent arrivals, they have clearly created a place for themselves to which they are welcoming me. I am the guest.

The relationship of guest and host is another one that is threaded throughout the Bible, particularly in relation to the theme of hospitality. Given the importance of hospitality in many ancient Middle Eastern cultures, this should not be a surprise. Think of Abraham welcoming 
the three strangers who turned out to be angels (Gen. 18). Ezekiel tells us that Sodom and Gomorrah were punished because they had 'excess of food and prosperous ease but did not aid the poor and needy' who migrated into their midst (Ezek. 16.49). In other words, they were insufficiently hospitable and host-like to those who needed it.

Jesus, naturally, complicates the understanding of hospitality. There are many stories of him attending meals as a guest. But occasionally, as in the case of Zacchaeus, he is a rather odd sort of guest, the kind that invites himself and makes someone else be the host. And when he does attend meals as a guest, he tends to give advice on how to be a good host. Once, while eating a meal at the house of a Pharisee, he decides the time has come to offer some advice on how to be both a good guest and a good host (Lk. 14.1-24). He tells the guests not to sit in the place of honor but sit in the lowest place. He says directly to his host, the Pharisee who invited him: 'When you give a luncheon or a dinner, do not invite your friends or your brothers or your relatives or your rich neighbours, in case they would invite you in return, and you would be repaid. But when you give a banquet, invite the poor, the crippled, the lame, and the blind' (14.12-13).

More fundamentally, the Incarnation is a moment of becoming a guest. The Word comes to dwell in our midst - but it does so as a helpless baby in a manger, who needs support from a mother and father who welcome him as their own and become his hosts. One way of phrasing the great truth of the Incarnation is that God in Christ empties himself to allow himself to be welcomed by humans, that is, to become the guest of humans. Yet in his parables, Jesus makes clear that it is God who is the ultimate host. The prodigal returns to his father wanting nothing more than to be a hired hand. But his father is the host and will not let him be anything less than an honored guest (Lk. 15.22-24). It is the Good Samaritan who unexpectedly becomes the host and makes the traveler, seen as the people of Israel in some interpretations, his honored guest (Lk. 10.25-37).

Not only is Jesus both the host and the guest, he is also sometimes the meal as when he tells his followers that the bread and the cup are his body and blood. I think of William Chatterton Dix's line, 'Thou on earth both priest and victim in the Eucharistic feast. ${ }^{9}$ For Dix, Jesus is both the host - the priest - but also the meal - the victim. The Eucharistic rite in the Anglican Church of Kenya puts it this way in its fraction sentence: 'Draw near with faith and receive. Christ is the host and we

9. 'Alleluia, Sing to Jesus!' Hymn 460 in The Hymnal 1982 (New York: Church Publishing, 1985). 
are his guests. ${ }^{10}$ Jesus invites us to his table in the Eucharist where we are guests to his host but when we arrive we find that he has become the meal. To turn to etymology again, we should note that the English words 'host' and 'guest' originate in the same Latin root word, hostis, which means stranger, sojourner, or visitor, and, occasionally, as the word suggests, enemy. (The word for host in reference to the body of Christ comes from a different Latin word, hostia, meaning sacrificial victim.) The point is not as strong because it is rooted in Latin and only works for the pair of words in English, but it nonetheless expresses the close and almost interchangeable relationship between host and guest.

Thinking about this pair of words in relation to the story of Bernard Mizeki and in relation to the witness of the Bible, I draw the clear and I hope uncontroversial lesson that Christians are people who are called to offer hospitality to all, to be the host, and to show this attitude particularly towards those who are peripheral or marginalized. That is precisely what SSJE was doing when it welcomed Bernard Mizeki into its midst. It was what Mizeki did when he welcomed catechumens into his new community. And not just Christians: Mangwende appears to have been a gracious host to Mizeki.

But we can follow this line of thought farther and acknowledge that not only are we called to be hosts, we are also called as Christians to be guests. Moreover, the people we are to make ourselves guests to are the very people, migrants, who we thought we were supposed to be hosting. In my experience, this is a much more difficult step for many people to take. I can think of many congregations with which I am familiar that have mission and outreach programs that are oriented around the idea of being a host: sponsoring refugees from overseas, cooking meals for a shelter, and so on. Judging from my own experience, I would suspect that many of those same people who are happy to be hosts would have much more difficulty in seeing themselves as guests.

I came face to face with this some years ago when I was engaged in an extended period of travel for what eventually became my book Backpacking through the Anglican Communion. ${ }^{11}$ The most exhausting part of that travel was simply having to be a guest all the time. When I spent two weeks in a diocese in northern Nigeria and stayed with the bishop and his wife, I found the hospitality smothering. We ate about five

10. Anglican Church of Kenya, Our Modern Services (Nairobi: Uzima, 2002), p. 82.

11. Jesse Zink, Backpacking through the Anglican Communion: A Search for Unity (New York: Morehouse, 2014). 
meals a day, the bishop's wife was constantly on her feet making sure I had exactly everything I needed, and the bishop insisted we watch CNN during dinner because, in his words, 'I know you Americans like CNN'. Eventually I told them to lay off: I didn't need to eat so much food, the selection of juices they had was just fine, and I'd be happy to talk to them rather than watch CNN. They were a little bit hurt, I think, and the bishop said to me, 'Jesse, you are the first visitor from another country to this diocese in sixteen years and the first since I have been bishop. We want to make sure everything is exactly right!' As I consented to the unexpectedly difficult spiritual discipline of being the guest, I realized that in allowing another person to be host, I was giving over a significant amount of power in the relationship. Allowing ourselves to be the guest, particularly when we are used to being the host and in a world church riven by unequal power relations, may be a small step towards mirroring the kenosis of Christ.

In thinking about guests and hosts, I find myself thinking of the passage in the First Letter of John: 'We love because he first loved us' (4.19). I am pretty comfortable replacing the verb 'love' with 'welcome'. We welcome because God first welcomed us. In the same way that God's grace welcomes us into God's forgiving embrace, we too are called to welcome others. Another way of saying this is, we become hosts because God first hosted us. That perhaps is what Bernard Mizeki thought: he had been welcomed by others and he was now extending that same welcome in the midst of Mashonaland. But we need to take a step further and say this: We allow ourselves to be welcomed because God in Christ first allowed himself to welcomed. In other words, we become guests because, in the Incarnation, the Son of God first became our guest. It is true that Bernard Mizeki became a host, but he was also always a guest of Mangwende and others who welcomed him. Mizeki allowed himself to be a guest to the point of his death.

Anglicanism has been seen as a religion that emphasizes the Incarnation. When Charles Gore and later Donald MacKinnon made these claims, they did so in part because they wanted Christians and the church to imitate the kenosis of Christ in the Incarnation, which they believed embodied the nature of Christ's moral authority. ${ }^{12}$

12. See, for instance, Charles Gore, The Incarnation of the Son of God: Being the Bampton Lectures for the Year 1891 (London: John Murray, 1891) and Donald Mackinnon, 'Kenosis and Establishment: Gore Memorial Lecture Delivered in Westminster Abbey, November 5, 1968', in Ashley John Moyse, Scott A. Kirkland, and John C. McDowell (eds.), Kenotic Ecclesiology: Select Writings of Donald M. MacKinnon (Minneapolis: Fortress Press, 2016), pp. 173-95. 
Whatever that Incarnational emphasis may now mean for Anglicanism, if we are to follow the logic of figures like Gore and others the point now may be to say that our emphasis on the Incarnation leads to an emphasis on making ourselves guests. Extending sympathy to migrants and interacting with people on the move are only first steps. The much more difficult task is to ask ourselves: In this situation of migration, how can I be the guest? And recall our previous pair of words: if we think of ourselves primarily as people who are tied to a particular place, as Anglicans do, it will be relatively easy to be hosts. It will be much harder to be the guests.

\section{Journey and Destination}

Journey may be over-used in describing our spiritual life but there is some merit to it. As we have already seen, the people of God and the Son of God himself were people who were on journeys: out of Eden, into Egypt, out of Egypt, into the Promised Land, into Babylon, back again, setting one's face towards Jerusalem, missionary journeys around the Mediterranean, and so on. The Bible describes Christians as people of the Way (Acts 9.2). Christians are people on the move.

What do people on the move need? We have some sense of this in reading stories about migrants and displaced people today. First, they need sustenance on the way. Rohingya refugees in Bangladesh need shelter, food, water, and other necessities to sustain their life. Second, people on the move need some sense of their destination. Whether it is Syrian refugees in Turkey or Lebanon or Jordan or Rohingyas in Bangladesh, they need the same thing that the Israelites wandering in the desert needed: the knowledge that this situation is only temporary, that their situation will come to an end, that the journey is not endless. It is this second bit that is so difficult to provide.

It can be harder at first to see how these words map onto the story of Bernard Mizeki. Mizeki was certainly on a journey for part of his life, though whether he saw it in these terms we do not know. More importantly, however, he offered a sense of a destination, namely the place that he was creating in the sacred grove. The destination was not necessarily that grove, however. Rather, it was the way of life that he represented and embodied. As has been noted of 'native catechists' like Mizeki, to Westerners they represent the distant end of the Western missionary and colonial effort, but to local Africans they represented a connection to approaching modernity. They were a way to access a larger, cosmopolitan framework that was making itself felt in the 
extension of colonial rule. ${ }^{13}$ In the crops he planted, the language he taught, the medicine he distributed, Mizeki represented a destination to which some Africans were now thinking they needed to turn. We can dispute how helpful a destination this was to embody, but I think it is clear that it represents a destination of sorts, even if offering such a destination was not part of Mizeki's explicit plan.

For the church, the word pair 'journey' and 'destination' is a challenge. In my experience, Anglicanism is not bad at providing sustenance for the journey. Indeed, I attended a church recently where at communion the words of distribution included the phrase 'strength for the journey'. Worship becomes a kind of sustenance for what is seen to be our real work in the world. But to speak of destinations in the Christian tradition is to speak eschatologically. It is no secret that liberal Protestantism in the North Atlantic world has largely relegated eschatology. Anglicanism has largely done the same. If people in society at large hear the word apocalypse today they are more likely to think of zombies, frankly, than Jesus. While in an earlier period of Anglican theology there may have been some effort to connect an emphasis on the Incarnation with an emphasis on eschatology, it is harder to see traces of that today. One of the most noteworthy recent voices that was both Anglican and eschatological was that of William Stringfellow, the lay Episcopal theologian who died in 1985. He wrote at length about the apocalyptic and rooted his biblical vision in the Book of Revelation. ${ }^{14}$

It is to Revelation that we can look to think about our destination. The great eschatological vision in Revelation is, importantly, a vision of a place, namely the new Jerusalem that John the Divine sees come down out of heaven (21.1-27). What can we say about this vision? First and not surprisingly, the vision of God's final consummation is a place. More than that, it is a particular place. It has so many gates, such and such a wall, with specific dimensions, particular jewels and other decorations, and a particular river. Second, God is clearly the host, but God cannot live without guests. God therefore brings this particular place to earth to make God's home among 'mortals'. We may be guests, but it is only by God coming to be in our midst that God is able to be our host. This means that this place has a kind of moral authority and moral dignity associated with it. In this place, we are enabled to be God's people. This is the culmination of our journey and the destination which we seek.

13. Adrian Hastings, The Church in Africa, 1450-1950 (Oxford: Clarendon Press, 1994), pp. 453-64.

14. Stringfellow considers Revelation at length in his An Ethic for Christians and Other Aliens in a Strange Land (Waco, TX: Word Books, 1973). 
Migrating people, whether refugees and displaced around the world or Christians in parish churches, need a sense of where they are going. Mizeki's story is a reminder that our communities may embody destinations without actually knowing it. That should prompt us to ask ourselves what sort of destination we embody in our communities of faith. Is it a destination in keeping with the coming reign of Christ and the kingdom he preached? Or does it represent another set of values of which we may only dimly be aware? Either way, if the church cannot speak eschatologically to those both within its walls and those without, then it will not matter how much sustenance we give to people on the journey. People want to know where they are going: the church needs to figure out what answer it can give to this question beyond 'strength for the journey'.

\section{Conclusion}

This exploration of migration and its relationship to Anglicanism has necessarily been limited. Given more time, there are more word pairs we could have explored related to migration, including citizen and foreigner. Such explorations await further work. Yet to conclude I want to highlight several broad points that arise from the story I have told and the word pairs I have introduced.

First, I want to make explicit a claim that has been implicit to this point: Bernard Mizeki is not alone. He is a representative of a much larger whole, namely African Anglicanism and African Christianity more generally. For Mizeki, migration led to religious change - he was baptized in Cape Town, not Mozambique - and this change led to further evangelism, mission, and church growth. This story is told time and again around the Anglican Communion. My own research in South Sudan, for instance, is in part the story of how the widespread displacement of civil war led to sudden and rapid religious change and the strengthening of the Anglican Church in that country. ${ }^{15}$ I have collected anecdotal examples of similar instances across Africa, in Nigeria, in Congo, in Mozambique, and elsewhere. We need more people studying African Anglicanism and as they do migration will be a particularly important part of their story. ${ }^{16}$ There are many other Bernard Mizekis

15. Jesse Zink, Christianity and Catastrophe in South Sudan: Civil War, Migration, and the Rise of Dinka Anglicanism (Waco, TX: Baylor University Press, 2018).

16. One person who has studied migration in the context of African Anglicanism is Emma Wild-Wood. See her Migration and Christian Identity in Congo (DRC) (Leiden: Brill, 2008). 
out there who are not in our church calendar but who nonetheless shape the faith we inherit.

Second, place. It may seem perverse for a talk on migration to highlight the importance of place, but it is where I have wound up. And not just any space but particular locations. Part of the tendency of our always-online digital world is to de-emphasize place. It was MySpace not MyPlace. So long as someone is in the digital space, they are equally able to consume fake news or Russian ads or celebrity gossip regardless of where they are. According to popular accounts, one way of interpreting the election of Donald Trump and the triumph of Brexit in the past 18 months is to see them as the assertion of particular places: England, not Europe; rural America, not metropolitan America. On this account, those elections represent the investing of particular places with moral dignity. Yet the paradox is that those campaigns were very much part of the technologies of our society that tend to diminish the significance and particularity of place.

It is time to reclaim the theological importance of place and its particularity. In the midst of our global public space, in which migrants use WhatsApp to communicate with one another while others use similar apps to marshal opposition to their presence, what Christians are called to, I believe, is the creation of public places. These public places will be local and particular. None will be exactly like another. But they will all be united by the common idea of associating moral authority and moral dignity with place. In other words, they will be a lot like parish churches.

People can claim their identity from place in a way that it is not possible to do with abstract spaces. Just as a particular parish is an instance of the universal church, so too our creation of particular places needs to always ensure we point to a larger link to the universal. We hear much these days in universities and elsewhere about the need for 'safe spaces'. Anglicans are called to create safe places. And in that distinction is a whole world of theology at which Anglicans, I believe, have the potential to be particularly adept.

Yet at least two caveats are in order. Our creation of places must be a creation of permeable places. For Christians know that just as in the law of the Hebrew Scriptures and as followers of the one who had no place to lay his head, we were once migrants too. Our places are to be local and particular but they are also to be open and permeable and not tied to any particular identity other than that found in the death and resurrection of Christ. Moreover, the story of Bernard Mizeki reminds us that the creation of place often involves the dislocation of other people for whom that place was important, particular, and even sacred. 
In North America, many Anglicans and Episcopalians have begun to recognize that their sacred places sit on land that was once sacred to whole populations of people who are now displaced. The Anglican Church of Canada has gone a long way in this direction, with much distance still to cover, and is likely soon to be launching a selfdetermining indigenous church. In Canada, I have participated in Anglican services that begin with a territorial acknowledgment that the service takes place in land that historically belonged to a now-displaced indigenous people. There is much to be said about this topic, but it perhaps suffices to say that there needs to be further exploration of the relationship between place and indigeneity. I perhaps should have begun this talk by acknowledging that this conference takes place on land that is the traditional territory of the Pawtucket, Massachusett, and Wampanoag peoples.

The third conclusion has to do with ourselves. At the heart of the Christian gospel is a message of change, repentance, and conversion. That change begins first and foremost with ourselves. The great gift of living in an age of migration is that it can lead to change within ourselves. In August of this year, thousands of Haitians were crossing the border into Canada from the United States and ending up in Montreal. A colleague of mine mentioned that on her drive into work she drove past the Immigration Canada office and saw a long line of people outside. It was these Haitians and others who were looking for help in finding a new place. She told me that she honked her horn and shouted out the window, 'We're glad you are here.' I, too, when I read the news today, have an innate sympathy with those who have been displaced. There are some pretty clear verses in the Bible that call me to precisely that. And my reaction is that of my co-worker: we are the host, you are the guest, and we are glad that you are here.

Too often, that sort of sympathy and that sort of hospitality are the end of the story - if we can even get as far as collective action as hosts. But this should not be where the story ends. As we broaden our places to create room for those who do not have a place, we acknowledge that we may end up displacing others, beginning with ourselves as we become guests of the very people we welcomed. We welcome because God first welcomed us. We allow ourselves to be welcomed because God first allowed Godself to be welcomed. What this migration crisis may remind us of is that perennial Christian truth, that change begins with us, that what is needed is a change in how we see ourselves, as simultaneously both guests and hosts bound together with others in the love of God.

I have sometimes asked my students if, in looking at the Bible, it can be said that God has a preferential option for the migrant. There are 
many ways in which I think that is true: God has a particular concern for those without a place. But it is also true that displacement is not the end of the story. In the tension between place and displacement, guest and host, journey and destination, we may find, as Bernard Mizeki once did, a new Christian identity and a deeper faithfulness to God. 